\title{
Comparative Constitutional Law in the Courts: Is There a Problem?
}

\author{
Cheryl Saunders*
}

\section{Introduction}

For more than a decade, ${ }^{1}$ debate has raged in the United States about the use of foreign law by courts in the course of constitutional adjudication. Much of the criticism of the practice denies its legitimacy, although there is also a growing focus on the methodology that courts employ. ${ }^{2}$ Controversy has been fuelled by occasional decisions of the Supreme Court often, but not always, involving application of the Bill of Rights, in which one or more Justices have included references to foreign legal experience in their reasoning and others have disputed their right to do so. ${ }^{3}$ In one much-quoted rejoinder, for example, Justice Scalia described

* Faculty of Law, University of Melbourne, Australia. The chapter was written in the course of a year spent in the Faculty of Law, University of Cambridge as Arthur Goodhart Visiting Professor of Legal Science.

1 Both the practice of citing foreign law and debate about it have a much longer genealogy, which can be traced to the first part of the nineteenth century: Steven G Calabresi and Stephanie D Zimdahl, 'The Supreme Court and Foreign Sources of Law: Two Hundred Years of Practice and the Juvenile Death Penalty Decision' (2005) 47 William and Mary Law Review 743; 753-5. Calabresi and Zimdahl argue that the practice has increased in significant respects since Trop v Dulles 356 US 86 (1958). The current, intense, phase of the debate foilows the use of foreign law in. Thomson $v$ Oklaboma 487 US 815 (1988); Wasbingtan v Glucksberg 521 US 702 (1997); and Printz v United States 521 US 898 (1997)

2 Richard A Posner, 'The Supreme Court 2004 Tèrm Foreword: A Political Court' (2005) 119 Harvard Law Review 31, 85-8 combining both types of critique in his analysis of the 'cosmopolitan court'.

${ }_{3}^{3}$ See in particular the following cases: Thompson v Oklahoma 487 US 815 (1988) (reference to the use of the death penalty in a range of jurisdictions by Stevens J, for the Court, at $830-1$; rejected by Justice Scalia, with whom Chief Justice Rehnquist and White J concurred, at 868-9 and n 4); Printz $\nu$ United States 521 US 898 (1997) (reference to foreign constitutional practice by Breyer J at 977, criticized by Scalia J at $921 \mathrm{n}$ 11); Atkins $\nu$ Vitginia 536 US 304 (2002) (reference to the views of the 'world community' by Stevens J, writing for the plurality, at 316, rejected by Scalia J, with whom Rehnquist CJ and Thomas J concurred, at 347-8); Lawrence v Texas 539 US 558 (2003) (reference to decisions of the ECHR and those of 'other nations' by Kennedy $\}$, writing for the plurality, at 576 , rejected by 
comparative analysis as 'inappropriate to the task of interpreting a stitution, although it was of course quite relevant to writing one'. 4 ,

The practice remains a topic of fierce debate among scholarsin United States ${ }^{5}$ and among judges writing extra-judicially. ${ }^{6} \mathrm{It}$ has beent subject of critical comment in the press. ${ }^{7}$ It has attracted the attentio of Congress, spawning a series of proposed resolutions seeking, in o way or another, to discourage juidicial reference to foreign constitution experience, with impeachment a veiled threat in the background 8 . 1 Th legitimacy of referring to foreign law for the purposes of constitution interpretation was raised with Justice John Roberts (as he then was) di. ing his confirmation hearings. ${ }^{9}$ His response was sharply dismissive of 1 t practice, suggesting that the debate is likely to continue.

Scalia J, with whom Thomas J concurred at 598); Roper $v$ Simmons 161 L Ed 2d 1 (200 (reference to 'the opinion of the world community' by Kennedy J, writing for the plural at 26 , criticized on methodological grounds by Scalia J, with whom Rehnquist $C]$ Thomas J concurred, at $61-4$, and also by $O^{\prime}$ Connor J, on methodological grounds 49-50, albeit specifically endorsing the potential relevance of foreign law). Of these foult cases, Printz was concerned with federalism; Atkins and Roper with the understanding 'cruel and unusual punishment' in the context of the Eighth Amendment and Lawrent with the application of the due process clause to the criminalization of homosexitial conduct.

4 Printz v United States 521 US 898, 921 in 11 (1997).

5 For a sample of scholars who broadly support the practice see Vicki C Jackso 'Constitutional Comparisons: Convergence, Resistance, Engagement' (2005). 110 Harvard Law Review 109; Harold Hongju Koh, 'International Law as Part of Our: (2004) 98 American Journal of International Law 43. Those critical of the practice inclitade Roger P Alford, 'Misusing International Sources to Interpret the Constitution' (200,4) American Joumal of International Law 57; Ernest A Young, 'Foreign Law and Denominator Problem' (2005) 119 Harvard Law Review 148.

6 See eg Ruth Bader Ginsburg, "A Decent Respect for the Opinions of [Human]kind The Value of a Comparative Perspective on Constitutional Adjudication' (2005) 6 Cambridge Law Joumal 575; see also Justice Stephen Breyer and Justice Antonin Scaliatio 'A conversation between US Supreme Court Justices' (2005) 3 International Journd ly Constitutional Law 519.

7 See eg Dana Milbank, 'And the Verdict on Justice Kennedy is: Guilty', Washingt Post, 9 April 2005.

8 Reaffirmation of American Independence Resolutions, H Res 568, 108th Congtess (2004); H Res 97, 109th Congress (2005), S Res 92109 th Congress (2005); see also HiRes 468, introduced on 21 November 2003: 'Expressing disapproval of the consideration by Justices of the Supreme Court of the United States of foreign laws and public opinion in their decisions, urging the end of this practice immediately to avoid setting a dangerous precederit and urging all Justices to base their opinions solely on the merits under the Constitution of the United States'. In addition, see Title II of the Constitution Restoration Bill of 2005 that 1 it enacted, would have prohibited any court from ' rely [ing] upon any constitution, law, admin. istrative rule, Executive order, directive, policy, judicial decision, or any other action of any foreign state or international organization or agency, other than English constitutional and common law up to the time of the adoption of the Constiturion of the United States'.

9 United States Senate Judiciary Committee, Hearing on the Nomination of Johi Roberts to be Chief Justice of the Supreme Court, Transcript, Day' Two, 13 September 2005
11. Inat be that the criticism has been exacerbated by certain features of Tases that have sparked the debate. In each case the issue at stake was thita was hotly contested in the United States of the late twentieth. deet ly twenty-first century: the constitutionality of the death penalty mentally impaired offenders ${ }^{10}$ or for minors; ${ }^{11}$ the constitutionality if 1 ine dils is the invalidation of congressional legislation on federalism

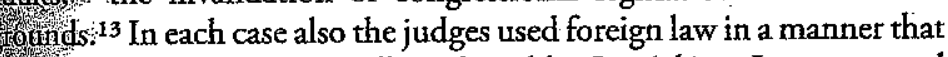
5. 4 istinctive and potentially vilnerable. In Atkins, Lawrence, and of er in one way or another, the references to foreign law assumed the peisuasive qualities of universalism. In these circumstances, comparative 717.16:木s: was not necessary for the purposes of the argument, exposing the najority justices to accusations of merely 'counting ... noses'. ${ }^{14}$ In P. 17laws by member states in Germany, Switzerland, and the European iron to cast 'empirical light' 15 on the constitutionality of the conferral 0ffecteral duties on state officials in the United States was open to attack H the ground that he failed adequately to take structural differences between the two types of federations into account. ${ }^{16}$ It is clear from the tho of the debate on the use of foreign sources in the United States, 19vever, that these features of the cases are not the sole cause of the eontroyersy. The criticisms are generalized and embrace all substantial teferences to foreign law.

7. A. controversy that attaches to the use of constitutional comparison by courts in the United States is in marked contrast to the position elseWhere in the common law world, ${ }^{17}$. where references to foreign law are freely nalde in all types of cases, without apparent concern about legitimacy and

riesponse to questions from Senator Kyl, <http://www.washingtonpost.com/wp-dyn/ oncent/article/2005/09/13/AR2005091301210.htmil $>$, viewed 24 June 2006.

10. Atkins v Virginia 536 US 304 (2002).

Roper $v$ Simmons 161 L Ed 2d 1 (2005).

2 Lawrence $v$ Texas 539 US 558 (2003).

1) printz $v$ United States 521 US 898 (1997).

4 Posner, $n 2$ above, 151, arguing that the methodology of "including foreign jurisdicins in the denominator of noses that count accords authoritative weight to their choices' enphasis supplied). 15 Printz v United States 521 US 898, 977 (1997).

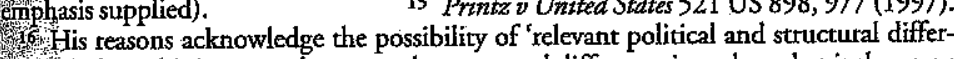
encest ibid. In this instance, howevet, the structural difference is so deep that it threatens hier relevance of the comparison altogether.

There is a growing literature on the use of foreign law by courts in civil law countries There is a growing literature on the use of foreign law by courts in civil law countries
150. see eg Guy Canivet, Mads Andenas, and Duncan Fairgrieve (eds), Comparative Law 1. 0. see eg Guy Canivet, Mads Andenas, and Duncan Fairgrieve (eds), Comparative Law
Before the Courts (London: British Institute of International and Comparative Law, 2004). 1. ity: in the style of their reasons for decision. 
with relatively little overt attention to method. ${ }^{18}$ The purpose of this chapter is to explore the reasons for the contrast and the implications of it from the perspective of countries whose courts make reference to foreign law often enough for the practice to be considered unexceptionable. Using the twin concerns about legitimacy and method to organize the argument, the chaptet focuses on two sets of questions in particular. The first seeks a better understanding of the attitude of most common law states towards the legitimacy of the use of foreign law in constitutional cases. Is it justified, and if so how and under what conditions? What insight, if any, does acceptance of the practice offer into the nature of constitutions and constitutional adjudication in such states: itself a potentially significant question for the purposes of comparative understanding? A second set of questions concerns the methodology employed by judges who make use of foreign law. Are there specific methodological concerns? If so, what is required? What, if anything, is the relevance of the debate on comparative method that is taking place within the discipline of comparative law, ${ }^{19}$ with its primary focus on private law, ${ }^{20}$ to the use of foreign law in constitutional adjudication?

The first part of the chapter is designed to scope the field of the inquiry. It justifies the exclusion of consideration of references to international, as opposed to foreign legal sources; explains the sometimes wavy line between constitutional and other forms of adjudication; and begins the laborious process of understanding the range of ways in which courts use foreign law. It introduces at this point a series of cases from a range of jurisdictions, to serve as concrete examples in the analysis that follows. The next two sections deal respectively with the challenges of legitimacy and methodology. The section on legitimacy considers not only legitimacy per se, but also certain aspects of judicial method that have the potential to raise the issue of legitimacy in another guise. The section on methodology thus can be confined to comparative method alone and

18 For an examination of the practice in Australia, by reference to a series of cases in which the High Court of Australia held that the Constitution provided some protection for freedom of political communication, see Cheryl Saunders; 'The Use and Misuse of Comparative Constitutional Law' (2006) 13 Indiana Journal of Global Legal Studies 37. For an analysis of practice in England, Canada, and South Africa, as well as selected civil taw countries, see Sir Basil Markesinis and Jörg Fedrke, 'The Judge as. Comparativist' (2005) 80 Tulane Law Reviezv 11 and the various commentaries on their article in the same issue.

19 For a selection of recent works, see Pierre Legrand and Roderick Munday (eds), Comparative Legal Studies: Traditions and Transitions (Cambridge: Cambridge University Press, 2003); Mark Van Hoecke (ed), Epistemology and Methodology of Comparative Law (Oxford: Hart, 2004); Esin Orucu, The Enigma of Comparative Law (Leiden: Martinus Nijhoff Publishers, 2004).

20 William Twining, Globalisation and Legal Theory (London: Butterworths, 2000), 185. facilitates examination of the relevance of the debate on methodology in comparative private law. The final section draws some brief conclusions, noting that greater attention to questions of the methodology that courts employ. in making reference to foreign constitutional experience may be timely, in order to preserve and enhance the practice itself.

\section{Scoping the Field}

\section{Foreign, Rather than International Law}

In order to clarify the issues raised by the use of foreign law, in terms of both legitimacy and method, references by courts to international law are excluded from the scope of the chapter.

In fact a case can be made, on various grounds, for including international law in a study of external doctrinal influences on constitutional adjudication. Most obviously, the dividing line between international and foreign constitutional law, never entirely distinct, ${ }^{21}$ is becoming increasingly blurred. What Gerald Neuman has helpfully isolated as the 'suprapositive' aspect of international human rights norms is reflected in many contemporary constitutional systems, albeit sometimes at a level of considerable generality. ${ }^{22}$ More significantly still, some Conștitutions ditectly incorporate international human rights norms and may in addition specifically authorize recourse to them for the purposes of constitutional interpretation. ${ }^{23}$ Further, in so far as the purpose of reference to external legal sources is to seek 'interpretative inspiration' 24 it may be met as well by international as by foreign domestic law.

21 See eg Jeremy Waldron, in the context of a discussion of ius gentium: "The distinction between international law and domestic law was much less crisp at the time Bentham was writing ... than it was in the middle of the twentieth century, and it has become less crisp again with the emergence of human rights law': 'Foreign Law and the Modern Ius Gentium' (2005) 119 Harvard Law Review 129, 135

22 Gerald L Neuman, 'The Uses of International Law in Constitutional Interpretation' (2004) 98 American Journal of International Law 82, 84. Neuman distinguishes this aspect of rights from their consensual aspect (signifying acceptance and consent) and their institutional aspect (the extent and manner of implementation).

${ }^{23}$ South Africa is a case in point The constitutional principles, on which the final Constitution was based, required universally accepted fundamental rights, freedoms and civil liberties' to be 'protected by entrenched and justiciable 'provisions': Interim Constitution, 1993, Appendix A, principle III. Courts are required to consider international law in interpreting the Bill of Rights: see Constitution of the Republic of South Africa, section 39(1)(b).

24 Aharon Barak, 'Comparative Law, Originalism and the Role of a Judge in a Democracy: A Reply to Justice Scalia', a paper delivered to the Fulbright Convention, 29 January 2006 (copy on file with the author). 
For these reasons, many courts and commentators refer to both foreign and international law, without clearly distinguishing between them ${ }^{25}$ This tendency is encouraged by the emergence of the phenomenon of supranational courts, with responsibilities for regional adjudication Such courts necessarily are themselves practitioners of comparative con stitutional law. ${ }^{26}$ More relevantly for present purposes, they also have:a dual character. From the standpoint of a member state they ate effectively international courts, with consequences for the hierarchy of norms that depend on the detail of the particular regional arrangement. From the standpoint of other states, however, such courts are foreign courts whose jurisprudence technically has the status of foreign law, even though the law reflects the standards of multiple states. ${ }^{27}$

For present purposes, however, the case for excluding international law from consideration is stronger still. The extent to which legal norms can and should converge across national boundaries is a controversial issue in comparative law. ${ }^{28}$ References by courts to international law necessarily assume a degree of convergence, within the limits of flexibility that inter national law itself allows. ${ }^{29}$ At a level of generality, which varies between different aspects of constitutional systems, convergence may in fact have occurred, either historically, as the natural consequence of the common foundation of western constitutional systems or more recently, through the processes of internationalization and globalization. Even where this is so, however, it does not necessarily extend to the level at which particular questions arise for constitutional adjudication. Excluding international law from this study makes it possible to avoid prejudging the question of whether references to external legal sources automatically involve the convergence of constitutional norms at this point. If the influence of international norms on constitutional law continues to deepen, however, over time it will become increasingly impracticable to isolate it from the use of foreign law.

25 See the discussion in Daphne Barak-Erez, 'The International Law of Human Rights and Constitutional Law: A Case Study of an Expanding Dialogue' (2004) 4 International Journal of Constitutional Law 611,612

${ }^{26}$ See eg the development of 'general principles of law' by the European Court of Justice from the constitutional traditions common to the member states: Anthony Arnull, The European Union and its Court of Justice (Oxford: Oxford University Press, 1999); $190-1$.

27 For an unusual example of a judicial exchange on this issue, in relation to a decision of the European Court of Human Rights, see Al Kateb v Godwin (2004) 219 CLR 562, 594, per McHugh J, 628 per Kirby J.

8 Orucu, $n 19$ above, 195-202

29 Ian Brownlie, Principles of Public Intemational Law (6th edn) (Oxford: Oxford University Press, 2003), 549-52.
Recourse by courts to international law also raises somewhat different uestions from the perspective of both legitimacy and.method. A state is bound by international law. ${ }^{30}$ International law thus has a claim to the attention of the.state, increasing its relevance to a court as a source of law, While making the manner in which the claim is made good a sensitive issue. Where a court unilaterally gives effect to an international norm, questions about separation of powers may be raised. ${ }^{31}$ Ironically, no doubt, obligation-free references to domestic foreign law raise no concerns on this score, even where the foreign law itself reflects international legal standards. On the other hand, references to foreign law raise a range of methodological questions, directed to ensuring that the comparison is well-founded, which are quite different to those presented by international law. ${ }^{32}$

\section{Constitutional Adjudication}

Asecond preliminary observation concerns the concept of constitutional adjudication itself. The principal focus of the chapter is on the use of forign law in the course of interpreting and applying formal written Eonstitutions. These constitute the core of constitutional law in most states. They also raise questions about legitimacy and methodology in their most acute form. It should be noted that, even thus confined, the stidy includes the full range of justiciable constitutional norms, dealing inot only with rights, but also with the organization of public power. Different aspects of constitutional law present different challenges for effective comparison and it is sometimes necessary to distinguish between them for this purpose.

On the other hand, it is neither desirable nor necessary to confine the topic too rigidly to written Constitutions and in what follows the boundaries are extended in at least two respects.

First, in most common law states claims under the common law and statute may arise in the course of constitutional adjudication in a manner that closely intertwines them with constitutional questions. ${ }^{33}$ Similarly,

30 ibid 34. 31 Young, $n$ 5 above, 163-5. 32 Brownlie, $n$ 29 above, 52-3

33 This is most obviously the case when a question arises about the impact of the Constitution on relations in private law. See eg Hill $v$ Church of Scientology of Toronto [1995] 2 SCR 1130; (1995) 126 DLR (4th) 129; Lange v Australian Broadcasting Commission (1997) 189 CLR 520; Du Plessis v De Klerk 1996 (3) SA 850 (CC). See generally D Friedman and D Barak-Erez (eds), Human Rights in Private Law (Oxford: Har Publishing, 2001); Andras Sajo and Renata Uitz (eds), The Constitution in Private Relations (Leiden: Eleven International Publishing, 2005). 
questions of process ${ }^{34}$ and interpretative technique 35 may bear both a common law and a constitutional character. Indeed, the juxtaposition of the common law and constitutional law in common law states is part of the explanation for the extension to constitutional adjudication of the long-established common law practice of drawing on foreign legal experience.

Secondly, some states do not have a formal written constitution. The United Kingdom and New Zealand are examples; as was Israel, at least before the Mizrahi Bank case. ${ }^{36}$ The experience of the courts of these states with the use of foreign law in determining questions that elsewhere would be likely to be covered by a formal constitution nevertheless is relevant to this study. This claim can be justified by reference to the United Kingdom as the most familiar, particularly challenging case. ${ }^{37}$ In the United Kingdom, it has so far has been possible to avoid introducing a formal, written constitution because institutions, principles, and practices of a constitutional kind have developed organically over time, drawing their legitimacy in large part from that process. The result, in the early years of the twenty-first century, is a quintessentially national legal and political construct of a constitutional kind, embedded in the culture of the state and with a structural logic of its own. Thus understood, questions about the use of comparative constitutional law by courts in the United Kingdom are similar enough to those that arise elsewhere, even after allowance is made for the absence of any formal distinction between constitutional and ordinary law. ${ }^{38}$

\section{Use}

Finally, the manner in which, in practice, courts use foreign law also has profound implications for the topic and thus needs to be canvassed at this stage. The variety of usage is vast, making it impracticable to design a typology that is sufficiently precise to be useful. Nevertheless, it is possible

34 For example, the issue of prospective overruling: see National Westminster Bank $v$ Spectrum Plus Limited [2005] UKHL 41, and the cases there cited from the United States, Spectrum Plus Limited [2005] UKHLL

35. For example, proportionality as a technique for evaluating the lawfulness of public action; or the use of preambles for the purpose of the interpretation of texts.

36 United Mizrabi Bank v Migdal Co-operative Village (1995) 49 (4) PD 221. For a statement of the present position see Barak $\mathrm{P}$ in Rubinstein $v$ Minister of Defence 52 (5) PD 481(High Ct, 1997) [31].

${ }^{37}$ See generally, David Feldman, 'None, One or Several? Perspectives on the UK's Constitution(s)' (2005) 64 Cambridge Law Journal 329.

${ }^{38}$ I may be that such a distinction is beginning to emerge: Thoburn v Sunderland City Council [2002] EWHC 195. to begin to grasp the phenomenon by organizing some of the principal variations in different ways that may be useful for different purposes.

One possible variation, which should be noted at the outset, is the nature of the foreign source on which a court draws. It may be a conclusion of law ${ }^{39}$ or a constitutional or legal norm, whether articulated by a court or otherwise. ${ }^{40}$ Equally, however, it may be an argument, ${ }^{41}$ a value, ${ }^{42}$ a perception, ${ }^{43}$ an interpretative approach, ${ }^{44}$ or merely a happy turn of phrase. ${ }^{45}$ The list is intended to be illustrative, rather than exhaustive.

A second type of variation is the stage in its reasoning at which a court refers to foreign experience. It may be used to assist to frame the question; ${ }^{46}$ to identify options or more generally to survey the field; ${ }^{47}$ to support a step in the argument; ${ }^{48}$ to suggest an answer; ${ }^{49}$ to test a

39 A redefinition of Parliament carnot be disregarded by a succeeding Parliament: Jackson v Attorney-General [2005] 3 WLR 733, 761 per Lord Steyn, citing various Commonwealth authorities.

40 The elements of qualified privilege in an action for defanation involving publication to an extended audience: Hill v Church of Scientology of Toronto [1995] 2 SCR 1 130, referring to New York Times v Sullivan 376 US 254 (1964). The horizontal division of power in the German federation is an example of another kind, although justified by reference to the 'empirical light' that it cast on the question before the Supreme Court of the United States in Printz $v$ United States 521 US 898 (1997), 976-7, per Breyer J.

41 'People cannot adequately influence the decisions which affect their lives unless they can be adequarely informed on facts ...', Lord Simon of Glaisdale, Attorney-General $v$ Times Newspapers Ltd [1974] AC 273, 315, to which Mason CJ referred in Australian Capital Television v Commonwealth (1992) 171 CLR 106, 139.

42 the fundamental imporcance... of freedom of communication ... in the modern system of representative government': Australian Capital Television v Commonwealth (1992) 171 CLR 106, 140, per Mason C).

${ }_{43}$ McGinty $v$ Western Australia (1995) 186 CLR 140, 187 per Dawson J: 'The democratic traditions of both Canada and Australia find their origins in the English model rather than in rebellion against it as is the case in the United States'.

44 The use of techniques of statutory interpretation to avoid invalidation of a statute: Rubinstein v Minister of Defence 52(5) PD 481(High Ct, 1997), Barak P, citing practice in the United States and Germany.

45 The 'chilling effect' of libel actions, to which reference is made in eg Australian Capital Television v Commonwealth (1992) 171 CLR 106, per Mason CJ, drawing on New York Times v Sullivan 376 US 254 (1964).

46 Laurie H Ackermann, "Constitutional Coraparativism in South Africa: A Response to Sir Basil Markesinis and Jörg Fedtke' (2005) $80^{\circ}$ Tulane Law Review 169, 185.

47 Executive Council of Western Cape Legislature v President of the Republic of South Africa 1995.(4) SA 877 (CC), available at < http://www.constitutionalcourt.org.za/site/thecourt/ cases/wpcape.pdf $>$ (viewed 17 July 2006)

48 Lange v Australian Broadcasting Commission (1997) 189 CLR 520, rejecting the United States state action doctrine as irrelevant to Australian circumstances, as a step leading to the conclusion that the Australian Constitution did not directly override the common law.

49 The goal of an electoral distribution might be to achieve 'effective representation' rather than 'equality of voting power': Reference re Electoral Boundaries Commission Act (1991) 81 DLR (4th) 16 La Forest, Gonthier, Stevenson and lacobucci JJ, drawn on by Dawson J in McGinty $\nu$ Western Azistialia (1995) 186 CLR 140, $186-7$. 
hypothesis; ${ }^{50}$ to confirm a conclusion; ${ }^{51}$ or to explore the consequenc of a particular result.52 Again, the list is not necessarily exhaustive.

A related variation concerns the nature of the impact of the foreig experience on the court's own deliberative processes. There is a distinc tion to be drawn here between constructive and reflective use. In the casse of the former, the foreign experience is used for guidance, in ways that range from quantifying the experience of states ${ }^{53}$ in order to determine universal or at least widespread practice, ${ }^{54}$ to the somewhat more com monly held purpose of deriving 'the full benefit of others' experience... solutions that have proved successful but also, scarcely less valuable, .... of solutions that have for any reason proved unsatisfactory'. ${ }^{5}$ Reflective use by contrast, is well captured by observations of Aharon Barak, President of the Supreme Court of Israel, that comparative law 'awakens judges to the potential latent in their own system' and 'allows for greater self knowledge'. ${ }^{56}$ There is an incomplete parallel here with yet another mode of analysing the use of foreign law, by reference to the acceptance, adap tation, or rejection of the foreign experience in question. Reflective use may often involve an awareness of difference and rejection of the foreign experience, but it will not always do so.

This multiplicity of usages of foreign legal experience is sometimes described in terms of dialogue, ${ }^{57}$ conversation, ${ }^{58}$ or, more recently

50 Ackermann, $\mathrm{n} 46$ above, 185.

51 Australian Capital Television v Commonwealth (1992) 171 CLR 106, 140: 'much the same view was taken in Canada ...', per Mason CJ.

52 Arguably, the purpose of the reference to Germany, Switzerland, and the European Union by Bteyer J in Printz $v$ United States 521 US 898, 976-7 (1997). See also Hill $v$ Church of Scientolagy of Toronto [1995] 2 SCR 1130, 1182, exploring commentary on the consequences of the adoption of the 'actual malice' standard in the United States.

53 Posner, n 2 above; see also Young, n 5 above, at 153 .

54 See eg the references to the views of the 'world community' in Atkins $v$ Virginia 53 US 304, 316 (2002) and in Roper v Simmons $161 \mathrm{LEd} 2 \mathrm{~d} \mathrm{1,} 26$ (2005).

55 Lord Bingham of Cornhill, 'The Break with the United Kingdom and the Internationalisation of the Common Law' in Peter Cane (ed), Centenary Essays for the High Court of Australia (London: Butterworths 2004), 84.

56 Aharon Barak, 'Foreword: A Judge on Judging: The Role of a Supreme Court in: Democracy' (2002) 116 Harvaid Law Review 16, 11 1, 110. See also Laurie Ackermann 'foreign law may stimulate "creative imagination"' (quoting Einstein), n 46 above, 185.

57 Honourable Claire L'Heureux-Dubé, 'The Importance of Dialogue: Globalization and the International Impact of the Rehnquist Court' (1998) 34 Tulsa Law Journal 15. See also the work of Sujit Choudhry, who has identified the 'dialogical' approach to comparative references by courts as a middle course between particularism and functionalism: Suji Choudhry, 'The Lochner Era and Comparative Constitutionalism' (2004) International Journal of Constitutiondl Law 1, 50-3; see also Sujit Choudhry, 'Globalization in Search of Justification: Toward a Theory of Comparative Constitutional Interpretation' (1999) 74 Indiana Law Journal 819.

58 Sarah K Harding, Comparative Reasoning and Judicial Review (2003) 28 Yale Jf International L 409, 424 referring to 'cross-border judicial dialogue or conversation'. engigement'. 59 Such formulations are useful to convey the complexity of the practice and to contrast it with applications of it that are particularly Winerable to criticism, including the borrowing or transplantation of 1. foreign law that assume universalism. The typically mixed usage of foris iglaw does not necessarily make methodological questions irrelevant, thewever. For present purposes, a more precise focus is required on the particularities of use.

To:assist in developing such a focus, three general propositions may be made. First, foreign legal experience is never treated as binding, at least in thelegal sense. In the words of President Chaskalson of the Constitutional Court of South Africa: 'We can derive assistance from ... foreign case law, but we are in no way bound to follow it'. ${ }^{60}$ Even direct borrowing is thelatively infrequent. ${ }^{61}$ Secondly, foreign legal experience is rarely used as an exclusive source of law and more often than not may play a relatively snill supporting role in the reasoning of a court, at least in quantitative tetmis: ${ }^{62}$ Thirdly, references to foreign experience are less likely to be nade when the domestic law is settled unless, at least, its suitability is guestioned in some way.

At most, foreign law is treated as persuasive. And in some cases, both the manner in which courts refer to a foreign decision and the effect of boing so is virtually indistinguishable from the use of domestic persuasive authority save for the acknowledgement that the source is foreign and therefore carries lesser weight. ${ }^{63}$ On the other hand, in many instances, Teferences to foreign law cannot readily be equated to the use of persua$s$ ive authority, at least in the traditional sense. Not all references to foreign hiw: are to principles of law formulated by courts, for example; and reflective use is more passive than the notion of 'authority' generally allows.

99 Jackson, $\mathrm{n} 5$ above.

so . State v TMakwanyane (1995) (3) SALR 391 (CC), [39].

661 In a survey of Canadian Chatter cases between 1998-2003, for example, Bijon Roy has calculared that only one of the sixty references to foreign legal experience involved a direct adoption of a foreign solution: Bijon Roy, 'An Empirical Survey of Foreign Iurisprudence and International Instruments in Charter Litigation' (2004) 62 University fToronto Faculty of Law Review 99, 130-1.

62 For a close analysis by reference to an Australian case study see Saunders, in 18 blove, 31 .

5:63 For an example see the reference to Commonwealth authorities in Jackson v AttorneyGeneral [2005] 3 WLR 733, 761. See also Justice Sandra Day O'Connor, Remarks to the South Center for International Studies 1-2, 28 October 2003, 'conclusions reached by other countries ... should at times constitute persuasive authority in American courts' available at $<$ http: $/ /$ www southerncenter.org/OConnor transcript.pdf $>$ (viewed 26 May 2006). See generally H Patrick Glenn; 'Persuasive Authority' (1987) 32 McGill Law Review 261. 
Even where a court refers constructively to a principle of law enunciated by a court in another jurisdiction, any analogy that it seeks to draw must have at least two dimensions: the relevance to the case in hand of the issues before the foreign court and the relevance of the legal experience of the other jurisdiction to that of the domestic court. In the words of Patrick Glenn, such a foreign source 'attracts adherence as opposed to obliging it'. ${ }^{64}$ Judges themselves often claim a role for foreign law far removed from the notion of persuasive authority. Thus Emeritus Justice Laurie Ackermann, formerly a Justice of the Constitutional Court of South Africa, has described the purpose of recourse to foreign law as seeking information, guidance, stimulation, clarification, or even enlightenment ... [o]ne is doing no more than keeping the judicial mind open to new ideas. 65

For present purposes, it is possible to define the field further, by confining consideration to references to foreign law that play a not insubstantial role in the reasoning of a court or of a member of it. Within the broad area of constitutional adjudication that remains, however, the reality that the manner in which foreign law is used varies widely complicates the task of generalizing about the methodology that should be applied.

\section{Selected Cases}

The discussion of legitimacy and method in the remainder of the chapter will refer from time to time to a series of case studies that are outlined briefly in this section. The cases are drawn from different common law or mixed common law jurisdictions: Australia, Canada, Israel, South Africa, and the United Kingdom. Collectively, they spari a range of constitutional issues encompassing, relevantly, questions about both institutions and rights. Individually and collectively, they also illustrate a variety of uses of foreign law in constitutional adjudication and of approaches to the use of foreign law. They are not otherwise distinctive, however. It would be possible to identify other cases within each jurisdiction, or cases in other jurisdictions, to perform a broadly similar role.

In McGinty $v$ Western Australia, ${ }^{66}$ the question for the Australian High Court was whether a wide disparity in the numbers of electors in State electorates, drawn pursuant to State law, was inconsistent with any limitation on State power that might be implied from principles of

$$
\begin{aligned}
& \text { 64 Glenn, n } 63 \text { above, } 263 . \quad \text { 6s Ackermann, n } 46 \text { above, } 183 . \\
& 66 \text { (1995) 186 CLR 140. }
\end{aligned}
$$

representative democracy inherent in the Australian Constitution. In a two-step reasoning process, the Court considered first whether a principle of equality of Commonwealth electoral boundaries could be implied from the Australian Constitution. It was referred in argument to judicial decisions from both the United States and Canada. The former favoured relatively strict numerical equality; the latter allowed other factors also to be taken into account in the interests of securing 'effective representation'.67

The validity of the legislation was upheld. ${ }^{68}$ While the majority justices differed to a degree in their conclusions about the scope of the protection for electoral fairness that the Constitution offered, none accepted a strict numerical standard. In the course of their reasoning, three of the four majority justices ${ }^{69}$ referred approvingly to the observation of McLachlin J, as Chief Justice of the Supreme Court of British Columbia, that Canada had a tradition of 'evolutionary' democracy, in contradistinction to the position in the United States where 'democracy... sprang from a revolution ushering in a new regime'. ${ }^{70}$ Seizing on the observation as applicable also to Australia, these judges rejected the United States approach.71 Justice Gummow went further, drawing on Canadian principles to fashion a doctrine that, in his view, applied to the Australian Constitution. ${ }^{72}$

While categories of use of foreign law inevitably are blurred at the margins, McGinty represents a case in which the High Court drew on both principles and perceptions in foreign case law, to identify and evaluate options available to it, in a manner that tended to be reflective rather than constrictive.

One issue before the Supreme Court of Canada in Hill $v$ Church of Scientology of Toronto ${ }^{73}$ was the consistency of the Canadian law of defamation with the principles of the Canadian Charter of Rights and Freedoms. ${ }^{74}$ In argument about whether the common law should be modified to bring it into line with the Charter, the Court was referred to applicable legal principles in Australia, the United Kingdom, and the

67 Reference re Electoral Boundaries Commission Act [1991] 2 SCR 158, 187-8, McLachlin J.

68 Brennan CJ, Dawson, McHugh, and Gummow JJ, Toohey and Gaudron JJ dissenting. 69 Dawson, McHugh, and Gummow JJ: Toohey J, in dissent, also preferred the Canadian approach, while drawing different conclusions from it: at $203-4$.

70 Dixon v Attorney-General (British. Columbia) (1989) 59 DLR (4th) 247, 262-3.
71 Dawson J at 186; McHugh J at 246-7; Gummow) at 266-8, 287-8.

72 At 287-8. 73 [1995] 2 SCR 1130; (1995) 126 DLR (4th) 129.

74 An earlier argument that action by the respondent Crown Attorney was governmental action and thus directly subject to the Charter failed: at 1162-4. 
United States, as well as to Canadian authority. In particular, the appellants urged the Court to accept the doctrine laid down by the Supreme Court of the United States in New York Times $v$ Sullivan, ${ }^{75}$ pursuant to which a public official must establish that a defamatory statement impugning his or her fitness for office was made 'with knowledge that it was false or with reckless distegard for whether it was false or not ${ }^{76}$ in order to succeed in the action.

The Court 77 refused to change Canadian law. In doing so, it used the United States experience in several ways: First, it identified some empirical consequences of the 'actual malice' standard in the United States, which had caused the doctrine to be criticized in that country and that made it undesirable in Canada also. ${ }^{78}$ Secondly, it distinguished $N e w$ York Times as the product of a particular social, political, and legal context that did not apply in Canada. ${ }^{79}$ In this connection it noted that the actual malice standard had also been rejected in England and Australia. ${ }^{80}$ Thirdly, it used the United States experience reflectively, to explore and explain the rationale for the differing standard in Canada, where greater weight is accorded to the reputation of the individual, thus reflecting the innate dignity of the individual, a concept which underlies all the Charter rights' ${ }^{81}$

Rubinstein v Minister of Defence 82 concerned the validity of the use of executive discretion by the Israeli Minister for Defence to defer military service for full-time students in religious seminaries, pursuant to a general statutory authority to grant defetrals ${ }^{83}$ and in circumstances in which 8 per cent of all those eligible for military service were granted a deferral on this basis. ${ }^{84}$ The challenge raised the issue of the division of power between the legislature and the executive. ${ }^{85}$ Barak $P$, with whom the other members of the Court agreed, restated the 'basic rule" that "primary arrangements" that determine general policy and the guiding principles must be enshrined in statute... whereas regulations or administrative guidelines must only determine "secondary arrangements"' 86 In the

$$
75 \text { (1964) } 376 \text { US 254. } 76 \text { At } 280 .
$$

77 Cory J, delivering the judgment of La Forest, Gonthier, Cory, McLachlin, Iacobucci, and Major JJ. L'Heureux-Dubé, who delivered a separate judgment, did not dissent on this point. 78 1183
$791180-1,1188$.
80 1185-6.
811179.
82 HC $3267 / 97$.

83 Section 36 of the Defence Services Law conferred such a power for a range of specified 'or other' reasons.

84 The distinction between 'administrative regulations' and an accumulation of 'individual acts' is not clearly drawn in the case, although see Barak $P_{\text {at }}[23]$ and in particular Cheshin J at [10].

86 [19]. event, the Court held that the exercise of discretion required a 'principled decision' of the Knesset, and was invalid. ${ }^{87}$

Both the basic rule and its application drew extensively on Israeli case law and secondary sources. Foreign law played a substantial role, however, in a somewhat unusual way, which may be attributable to the unusual nature of the Israeli Constitution, ${ }^{88}$ as a series of Basic Laws that underwent a process of 'constitutionalization' through judicial decision. ${ }^{89}$ In his reasons for decision, President Barak linked the basic rule identified by the Court with the underlying constitutional principles of separation of powers, the rule of law, and substantive democracy.90 $\mathrm{He}$ explained the relevance of these principles and drew conclusions from them about the boundary between legislative and executive power by reference to both Israeli and foreign sources; the latter comprising decisions from the United States, Germany, Canada, and the European Court of Human Rights. ${ }^{11}$ Foreign sources thus provided constructive support for the legal doctrine developed by the Court as well as contributing to an understanding of the rationale for it.

In Executive Council of Western Cape Legislature v President of Republic of South Africa ${ }^{92}$ the Constitutional Court of South Africa also was concerned with the scope of executive, vis-à-vis legislative, power. In this case, the question was provoked by legislation conferring authority on the President to. amend the parent Act or any schedule to the Act. In purported exercise of this authority, the President had amended the principal Act. The substance of the amendments was contested by the Western Cape Legislature. If the delegation was not valid, under the new interim Constitution of South Africa, it followed that the amendments were invalid as well.

As is normally the case, the scope of legislative authority to delegate was not specified in the interim Constitution. Very wide delegations had been permitted under the apartheid regime. ${ }^{93}$ The earlier cases could not be determinative, however, under the 'new constitutional order' ${ }^{94}$ In these

87 [43]. The operation of the order was, however, postponed for twelve months.

88. I owe this insight into a possible reason for the difference in the style of using foreign law in Israel to Professor Amnon Reichunan, of the University of Haifa.

89 United Bank Hamizrachi Ltd v Migdal Cooperative Village PD 49 (4) 221.

90 See also Cheshin P: ' . . in a social framework government by the Rule of Law .... in a society in which governmental powers and the power to coerce are divided between the legislative and executive branch; in a society in which human rights are at the pinnacle; in these social-governmental frameworks, first principles unequivocally instruct us that the broad exemption granted to Yeshiva students must be prescribed by statute. I unteservedly concur...'[7].

92 CCT 27/95. 93 Chaskalson $P$, at [52]. . 94 ibid.
91 [20]-[22]. 
circumstances, members of the Court explored options identified by the constitutional law of a range of other countries: the United Kingdom, the United States, Ireland, Australia, Canada, and, with some hesitation, India. ${ }^{95}$ These options differed. The United States and Ireland drew a distinction between delegating power to make law and delegating power to make rules 'giving effect to principles and policies which are contained in the statute itself ${ }^{96}$ Countries in the British constitutional tradition, on the other hand, tended to tolerate a wider delegation of legislative power. In the event, despite the broad structural similarity between the constitutional arrangements in South Africa and in other parliamentary systems, a majority of the Court favoured the United States and Irish approach, concluding that the interim Constitution at least precluded delegation to the executive of power to amend the Act by which the delegation was conferred. .7

The fifth and final case, (R) Jackson v Attorney-General, 98 is a decision of the House of Lords. The issue in dispute was the validity of the Hunting Act 2004, enacted without passage through the House of Lords, in reliance on the procedure established by the Parliament Act 1911, as amended by the Parliament Act 1949. The 1911 Act had modified the composition of the Parliament in the circumstances to which it applied. The 1949 Act had modified the procedure prescribed by the 1911 Act, using that procedure for the purpose. The claimant attacked the validity of the Hunting Act through the validity of the 1949 enactment procedure. He argued, in essence, that the law-making process established by the Parliament Act 1911 was not a primary law-making process; that in consequence there were implied, as well as express limitations on its use; and that, in particular, the procedure could not be used to amend the 1911 Act itself.

The challenge failed. The Parliament Act procedure was held to have created a 'new way of enacting primary legislation', 99 which could be used to change the details of the enactment mechanism itself. In so deciding, the Court necessarily rejected an argument for the claimant that drew on

95 The hesitation was caused by concern about the accuracy of the information about the Indian position that was available to the Court: Chaskalson [57]; cf Mahomed DP at [134].

${ }_{96}$ Cityview Press Ltd v An Chombairle Oiliuna [1980] IR 381, 395, quoted in the Western Cape case at [54].

97 Chaskalson P with whom Langa J concurred. Ackerman, O'Regan, and Kriegler JJ would have gone further to preclude any-delegation of power to amend an Act of Parliament. Mahomed and Sachs JJ would have evaluated each delegation by reference to a range of factors. Madala J and Ngoepe AJ reached their decision on another point.

98 [2005] 3 WLR 733. 99 Lord Bingham, at 745.
Australian ${ }^{100}$ and South African ${ }^{101}$ cases to establish that a derivative law-making process, which on one view the 'controlled' constitutions of the former dominions represent, ${ }^{102}$ could not be used to alter the terms in which it was conferred, without express authority to that effect. The argument failed, in part because the cases were distinguished on factual and constitutional grounds ${ }^{103}$ and in part because the claimant failed to convince the Court that the cases established the proposition for which they were advanced. 104

The outcome in Jackson has potentially deeper constitutional significance, however, causing at least two members of the House of Lords to use the foreign authorities in another way. Jackson establishes that the Parliament can redesign itself so as to provide an alternative primary legislative process that can be used for particular purposes. It raises a question whether Parliament can also redesign itself so as to provide an alternative primary legislative process that must be used for particular purposes; in effect providing a basis for the entrenchment of constitutional arrangements in the United Kingdom. Both Lord Steyn and Baroness Hale drew on the Australian and South African cases to provide a basis for such a conclusion ${ }^{105}$ even though, in the words of Baroness Hale, the decision was 'for another day'. ${ }^{106}$ The Commonwealth authorities are used constructively, as a form of persuasive authority, in a manner that, at least in the case of Lord Steyn, only lightly distinguishes them from domestic cases.

\section{Legitimacy}

Legitimacy and illegitimacy, as Joseph Weiler once remarked in the context of a discussion of the European Union, are 'notoriously elusive

100 Attorney-General for New South Wales v Trethowan (1931) 44 CLR 394; Taylor v Attorney-General of Queensland (1917) 23 CLR 457; Clayton v Heffron (1960) 105 CLR 214; see also Owen Dixon, 'The Law and the Constitution', 51 LQR 590.

101 Harris v.Minister of the Interior 1952 (2) 428 (AD); Minister of the Interior $v$ Harris 101 Harris v. Minister of the Interior 1952 (2) 428 (AD); Minister of the Interior $v$ Harris
1952 (4) 769; see also D V Cowen, Parliamentary Sovereignty and the Entrenched Sections of the South Africa Act (Cape Town: G-VG Juta, 1951).

${ }_{102}$ In this context the term 'deriyative' was used to distinguish law-making procedures the validity of the exercise of which is 'open to investigation in the courts' from procedures where this possibility is not recognized: Lord Bingham at 744 . This analysis is preferable to the analogy that also was drawn with delegated legislation. Neither captures the conception of a different notion of parliamentary sovereignty that now prevails in the former dominions: see eg Attorney-General (WA) v Marquet (2003) 217 CLR 545, 570, Gleeson CJ, Gummow, Hayne, and Heydon JJ.

${ }_{103}$ [2005] 3 WLR 733, 750, Lord Bingham. 104 At 162, Baroness Hale.

ios Lord Steyn, 761-3; Baroness Hale, 783-4. 106 At 784. 
concepts' ${ }^{107}$ One of the causes of the difficulty is that legitimacy may be viewed objectively or subjectively and evaluated normatively or empit ically. ${ }^{108}$ In relation to institutions of government, including courts; democracy supplies a familiar normative measure and elite and publie acceptance can be used for empirical purpöses, however problematic these may be. ${ }^{109}$ The normative rationale necessarily must take into account the role that courts play and are expected to play in a democratic society, in upholding the constitution and maintainitig the tule of law.

It is not necessary for present purposes to engage in depth with the problem of judicial review in democratic theory. Whatever the basis on which judicial review is accepted and explained, the inquiry here is more narrowly confined to the question of whether recourse to foreign law makes a difference to its legitimacy. This section distinguishes two distinct ways in which the question of legitimacy might be raised by the use of foreign law. First, it may. be argued that a court is never justified in considering foreign sources in the course of constitutional adjudication: subject to, perhaps, minor exceptions. This form of difficulty is referred to here as the problem of legitimacy per se. Secondly, even if references to foreign law are acceptable in principle, questions about legitimacy may be raised indirectly by the way in which the foreign experience is used or, in other words, by judicial method.

\section{Legitimacy Per Se}

References to foreign law may automatically be denied legitimacy because the sources on which a court may draw for constitutional adjudication are regarded as closed. There are several possible explanations for a view of this kind.

One group of explanations denies the legitimacy of judicial recourse to foreign law by reference to considerations deriving from the domestic constitutional system that are deemed to preclude the practice. It has been suggested; for example, that restrictions on the use of foreign law might be inferred from the logic of the judicial appointment process, through which the legitimacy of the judicial tole is reinforced by the democratic legitimacy of the elected branches. ${ }^{10}$ It may be that this

${ }_{107} \mathrm{~J} \mathrm{H} H$ Weiler, 'Epilogue' in Anne-Matie Slaughter, Alec Stone Sweet, and J H H Weiler, The European Court and National Courts-Doctrine and Jurisprudence (Oxford: Hart Publishing, 1998), 372.

${ }_{108}$ Christopher W Morris, An Essay on the Modern State (Cambridge: Cambridge University Press, 1998), 102.

ino Posner, $n 2$ above, 88-9. encern is tied to the use of foreign law to establish universal practice although, even in this context, it seems exaggerated. ${ }^{111}$ It appears neverthieless to be shared by Chief Justice John Roberts who, in the course of inis confirmation hearing, observed that:

fwe're relying on a decision from a German judge about what our Constitution neans, no president accountable to the people appointed that judge and no Senate accountable to the people confirmed that judge. And yet he's playing a role If shaping the law that binds the people in this country.112

An alternative consideration, of a somewhat different kind, involves the authority for the Constitution itself. The sources on which a court may draw in the course of constitutional adjudication need not be considered closed merely because the Constitution is seen as an exercise of sovereignty on the part of the people of the state concerned. Popular sovereignty is a theoretical construct that serves to legitimize the status of a constitution as fundamental law and may have other, practical, implications for the attitude of the governors to the governed. It does not necessarily confine the sources to which a court may turn in interpreting the Constitution and developing the reasons for its decision. But a foundation in popular sovereignty that is coupled with an approach to law that understands it purely as an exercise of will, ${ }^{113}$ or with an approach to constitutional interpretation that demands fidelity to the intention of the framers or to the expectations of the national community of the time, ${ }^{114}$ may present impediments to the use of foreign sources, as well as confining the process of constitutional interpretation in other ways.

There is a second type of explanation that suggests another basis on which the sources for constitutional adjudication may be considered closed. In a recent article in the Harvard Law Review, Jeremy Waldron argues the need for a theory that positively justifies recourse by courts to all sources on which they draw and that identifies and explains the key features of the practice. ${ }^{115}$ In relation to domesticlaw Waldron finds such

111 'To cite foreign decisions in order to establish an international consensus that should have weight with US courts is like subjecting legislation enacted by Congress to review by the United Nations General Assembly' ibid 89.

112 United States Senate Judiciary Committee, Hearing on the Nomination of John Roberts to be Chief Justice of the Supreme Court, Transcript, Day Two, 13 September 2005 in response to questions from Senator Kyl, <http://www.washingtonpost.com/wp-dyn/ content/article/2005/09/13/AR2005091301210.html >, viewed 24 June 2006.

113 Waldron, $\mathrm{n} 21$ above, 147.

114 Barak, n 24 above, discussing both intentionalism and originalisn.

115 Waldron, n 21 above, 129. See also Mark Tushnet, "The Possibilities of Comparative Constitutional Law' (1999) 108 Yale Law Journal 1225, seeking 'authority' for use of foreign law. 
a theory in the doctrine of precedent. ${ }^{116}$ In relation to foreign law, he suggests that a theory might be based upon a modernized conception of ius gentium. By analogy with scientific method, ius gentium might be perceived to represent the established deliverances of legal science ... more than a sum of its parts ... a dense and mutually reinforced consensus ...' ${ }^{117}$

Waldron's argument is directed specifically to the issues raised by references to the standards of the 'world community' in resolving the kinds of moral questions presented in Atkins and in Roper. He accepts that the actual practice in those cases does not conform to the standards that his theory prescribes. ${ }^{118}$ Nor does his theory seek to cater for the significantly more diverse use of foreign legal experience that in fact occurs elsewhere. Thus, if there is a need for a theory to legitimize the practice of referring to foreign law more generally, the need is not satisfied by the possibilities of ius gentium. On the other hand, to the extent that Waldron's argument calls for a theory about how foreign law is used, as opposed to whether it can be used at all, he can be understood as raising concerns about judicial method, rather than about legitimacy per se.

\section{The Perspective from other Common Law Countries}

Many of the arguments against the legitimacy of the use of foreign law that have currency in the United States are inpersuasive elsewhere in the common law world, for reasons that are in large part to do with attitudes to law, including constitutional law, and to judicial reasoning.

The starting point is the nature of the common law itself. Over centuries, the common law has been developed by its judges drawing on ideas from both within and outside the home jurisdiction. As long as the ideas are used appropriately, with due regard to the hierarchy of domestic legal sources in accordance with the prevailing theory of precedent, common law states do not recognize any normative or empirical reason why judges should be confined in the sources from which ideas come. Patrick Glenn has described this process as 'law as inquiry' as opposed to 'law as national response'. ${ }^{119}$ The distinction parallels Waldron's dichotomy between law as reason and law as will. ${ }^{120}$ If law is conceived of as reason, he argues, we 'may well be willing to approach it in a scientific spirit that relies not just on our own reasoning. but on some rational relation between what we are wrestling with and what others have figured out'. ${ }^{121}$

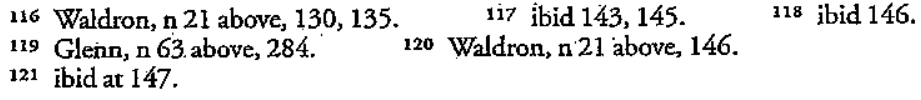

The origins of this approach to law lie in the history of the common law also recounted, for this purpose, by Glenn. ${ }^{122}$ The habit of drawing on other legal sources, from both within England and outside it, was developed early by common law judges: 'for centuries ... the common law existed in a kind of perpetual, institutional debate with other laws'. ${ }^{123}$ The success of the practice, from the standpoint not only of the competitiveness of the common law courts but also, and more importantly, of the quality of the body of substantive law, underpinned its acceptance. Comparable sentiments were expressed by Edmund Burke, in 1790: "We are afraid to put men to live and trade each of his private stock of reason; because we suspect that this stock in each man is small, and that the individuals would do better to avail themselves of the general bank and capital of nations; and of ages?. ${ }^{124}$

The practice survived the loss of flexibility that followed the introduction of the doctrine of precedent ${ }^{125}$ and persisted in the face of the emergence of distinct nationalisms, with their associated demands. ${ }^{126}$ Persistence was made possible by the continued reliance of common law states on judge-made law and by the independence of a common law judiciary, resisting nineteenth-century pressures to create national identity through law. ${ }^{127}$ The United States emerged as an exception, for reasons that range from the conception of law itself to the volume of law generated by the multiple American jurisdictions. ${ }^{128}$ The common law practice of drawing on foreign legal sources enjoyed a renaissance in the latter part of the twentieth century, ${ }^{129}$ for reasons that almost certainly include the new and extraordinary ease of access to foreign legal experience by electronic means. ${ }^{130}$

A cynic might suggest the lingering effects of empire as a somewhat dismal alternative explanation for the ready recourse of common law courts to the legal experience of other Commonwealth countries. ${ }^{131} \mathrm{It}$ may also be that examination of patterns of foreign citation would suggest that this is closer to the truth than one might wish. ${ }^{132}$ On the other hand, again

${ }^{122} \mathrm{H}$ Patrick Glenn, Legal Traditions of the World (2nd edn) (Oxford: Oxford University Press, 2004). 123 ibid at 256. ${ }_{124}$ Edmund Burke (J C D Clark ed) Reflections on the Revolution in France (Stanford, Calif: Stanford University Press, 2001), 251.

125 J P Dawson, The Oracles of the Law (Ann Arbor: The University of Michigan Law School, 1968).

126 Glenn, n 122 above, 247, 257. 127 ibid at $248 . \quad 128$ ibid at 249 . See also Glenn, $n 63$ above, 268.

129 Glènn, $\mathrm{n} 122$ above, 245.

130 See also the suggestions in, eg Young, $n 5$ above, 156 that the phenomenon is due also to more frequent meetings between judges. 131 Saunders, n 18 above, 25 . 132 It would be interesting to explore, for example, the exterit to which emphases in patterns of citation reflect former colonial links between the United Kingdom, Australia, 
following Glenn, ${ }^{133}$ it is possible to see the imperial interlude as part of the same story. The second British Empire reached its zenith around the same time as the doctrine of stare decisis took hold, minimizing the effect of the latter development by providing a larger law area within which authorities carried binding force actoss jurisdictional boundaries. The typically gradual, evolutionary process by which the colonies acquired independence removed from Commonwealth courts the obligation to follow each other without depriving them of the authority to continue to draw ideas from each other; a practice that was extended, once the constraints of empire were broken, to the courts of other jurisdictions as well.

It is one thing to claim that courts have authority to refer to foreign legal experience in developing the common law and another to claim legitimacy for the practice in the more distinctively national context of constitutional adjudication.

For the purposes of considering this question it is convenient to put aside the growing number of instances in which a Constitution itself authorizes recourse to foreign law. An example of a provision that explicitly authorizes courts to 'consider foreign law' can be found in the Constitution of South Africa. ${ }^{134}$ Significantly for present purposes, while the explicit constitutional authority is confined to the interpretation of the Bill of Rights, the practice of referring to foreign law in the course of constitutional interpretation in South Africa is familiar in relation to other parts of the Constitution as well. ${ }^{135}$ Authority to consider external sources of law can also be inferred in relation to constitutions that prescribe the extent to which rights might be limited by law by reference to limitations that 'can be demonstrably justified in a free and democratic society'. ${ }^{136}$

Even in the absence of constitutional authority of these kinds, the prevalence of the practice of referring to foreign law in the course of constitutional adjudication in common law states suggests an absence of concern about legitimacy. Thus in none of the five cases identified earlier was the legitimacy of reference to foreign law an issue. The explanation

Canada, and New Zealand through the Privy Council. An affirmative answer would not conclude the question, however, given other similarities between these countries. For a veiled suggestion that citation practice also may reflect old assumptions of racial superiority, see Upendra Baxi, 'The Colonialist Heritage' in Legrand and Munday $\mathbf{n} 9$ above, 46.

133 Glenn, $n 122$ above, 257.134 Section 39(1)(c).

135 The Western Cape decision illustrates the point. See also Ackermann, $n 46$ above, 175: 'I have not the slightest doubt that ... the Court would have placed the same reliance on foreign law even had there been no such provision in the Constitutions'.

136 Canadian Charter of Rights and Freedoms, section. 1. See also Constitution of the Republic of South Africa, 1996, section 36(1). lies in a combination of the pragmatism of the common law and of attitudes to both Constitutions and constitutional interpretation in most common law states. The advantages of treating law as inquiry or as a matter of reason apply no less in relation to constitutional law than to other forms of law. The extension to constitutional law of the technique whereby judges sometimes use foreign legal experience to inform their own understanding of national legal problems and solutions is encouraged by certain characteristic features of constitutions. ${ }^{137}$ They are designed to last for lengthy periods notwithstanding changes in national circumstances, whether they in fact do so or not. Typically, as a consequence, they are written in general terms, leaving considerable discretion to the judiciary, as the final interpreter in systems that recognize judicial review. Selfevidently, they draw on a political philosophical tradition that is shared by others. Importantly, there is nothing about the conception of a Constitution in these states or about the manner of constitutional interpretation that acts as a bar to recourse to foreign constitutional experience, methodological objections apart. The evolutionary tradition of which they are part assumes a degree of constitutional evolution over time, through judicial interpretation and without formal change, although the extent to which this can properly occur is contested. Judicial techniques are adapted as necessary to the needs of constitutional adjudication, but there is no suggestion that these proscribe optional recourse to foreign legal experience.

\section{Judicial Method}

The legitimacy of judicial review itself, however, requires the judiciary to maintain a somewhat delicate balance between giving the Constitution appropriate effect through the process of adjudication and trespassing onto fields that belong to the elected branches of government. Exactly where the balance is struck varies between states. How it is struck is in large part the stuff of judicial method, on which there is greater agreement, at least at a general level. Judges are expected to act impartially; to provide public, reasoned, explanations for their decisions; and to administer justice according to law. ${ }^{138}$ What 'law' requires for this purpose is contested. On any view, however, common law judges have considerable

137 See also the suggestion by Aharon Barak that the approach to constitutional interpretation is itself a part of the 'common law of the system', offering another explanation of the legitimacy of appropriate use of foreign law in constiturional interpretation where foreign law can also be used in adjudicating non-constitutional cases: Barak, $\mathbf{n} 24$ above, 7 .

138 A M Gleeson, 'Judicial Legitimacy' (2000) 20 Australian Bar Review 4. 
discretion, which nevertheless is bounded by a range of presumptions and techniques emanating from the common law itself. 139

One of the criticisms sometimes made of judicial use of foreign sources is that it alters the balance between courts and the other branches to a degree that affects the legitimacy of judicial decision-making. Broadly, the concerns are twofold. The first is that recourse to foreign legal experience expands and may serve to conceal expansion of the scope of judicial discretion beyond accepted bounds. The second is that it enables the outcome of a decision to be manipulated by unprincipled selection of foreign experience; in a manner sometimes described by the deceptively innocent term of "cherry-picking. ${ }^{140}$ Thus again to quote Justice Roberts, in the course of his confirmation hearings:

... foreign precedent doesn't confine judges ... Domestic precedent can confine and shape the discretion of the judges. Foreign law, you can find anything you want. If you don't find it in the decisions of France or Italy, it's in the decisions of Somalia or Japan or Indonesia or wherever. As somebody said in another context, looking at foreign law for support is like looking over a crowd and picking out your friends .... And that actually expands the discretion of the judge. It allows the judge to incorporate his or her own personal preferences, cloak them with. the authority of precedent ... and use that to determine the meaning of the Constitution. ${ }^{141}$

The charge that recourse to foreign legal experience unacceptably expands judicial discretion receives greater credence from the reality that judges often refer to foreign sources in dealing with novel cases or with cases in which previously settled national law is undergoing change. These are cases in which the discretion of a judge in any event approaches its outer limits. They are also cases that are likely to attract the most attention and, in some circumstances, controversy. Such cases must be determined, however, with or without the insights offered by comparative law. In at least some such cases, foreign experience can help to elucidate the issues and options for their resolution. It has potential to contain, rather than expand, the discretion of a judge, identifying directions that others.

139 Michael McHugh, 'The Judicial Merhod' (1999) 73 Australian Law Journal 37.

140 Christopher McCrudden, 'A Common Law of Human Rights? Transnational Judicial Conversations on Constitutional Rights' (2000) 20 Oxford Journal of Legal Studies 499; Yash Ghai, 'Sentinels of Liberty or Sheep in Woolf's Clothing? Judicial Politics and the Hong Kong Bill of Rights' (1997) 60 Modern Law Review 459.

${ }_{141}$ United States Senate Judiciary Committee, Hearing on the Nomination of John Roberts to be Chief Justice of the Supreme Court, Transcript, Day Two, 13 September 2005, in response to questions from Senator Kyl, < http://www.washingtonpost.com/wp-dyn/ content/article/2005/09/13/AR2005091301210.html>, viewed 24 June 2006. have taken and enabling evaluation of their consequences, while leaving the judge free to craft a domestic solution. Emeritus Justice Laurie Ackermann has suggested further that a 'comparative legal approach' can give judges insight into their own prejudices and assist in eliminating personal preferences. ${ }^{142}$

The impact of the use of foreign law on judicial discretion can be explored further by reference to the five cases outlined earlier. Expansion of judicial discretion was not an issue in Hillor Mc Ginty, in both of which foreign law was used reflectively and in neither of which did it contribute to significant doctrinal change. In Rubinstein, Western Cape, and Jackson, however, foreign law was used in circumstances capable of raising questions about judicial discretion. In Jackson the issue is de minimis in the sense that the constructive conclusion from foreign law ${ }^{143}$. was drawn by only two of the judges and clearly represented obiter dicta. The conclusion heralded a significant legal development, however. Relevantly for present purposes, moreover, Lord Steyn did not consistently distinguish between the domestic and Commonwealth sources to which he referred, although the distinction is likely to be obvious enough to most of his readers.

In both Rubinstein and Western Cape, on the other hand, the manner of reference to foreign law followed a pattern that is more typical in such cases. Domestic authorities were examined first; foreign authorities were considered subsequently and were clearly identified as such. In Western Cape, moreover, the reasoning of the justices who considered foreign law was explicit about the purposes for which it was used and hence the weight to be accorded to it. ${ }^{144}$ In Rubinstein, by contrast, there was no explicit reference to the authority of the foreign sources, leaving this to be inferred from their provenance.

If concern about the impact of comparative law on judicial discretion has any foundation at all, it can be alleviated in obvious ways. The first is by distinguishing foreign from domestic sources. In practice this is rarely. a problem; the distinction is generally made by courts automatically, as part of the normal process of categorizing sources in the course of judicial reasoning. ${ }^{145}$ The second is by more explicitly identifying the role that foreign law plays and the weight accorded to it. This is an aspect of a

142 Ackerman, $n 46$ above, 192.

143 That Parliament cannot disregard a redefinition of itself for a specific purpose: [2005] 3 WLR 733, 761 .

144 See for example Chaskalson P: 'This brief and somewhat limited survey of the law as it has developed in other countries is sufficient to show that ...', at [61].

${ }_{145}$ In some courts, of which the Supreme Court of Israel is an example, the list of cases cited also distinguishes between domestic and foreign sources. 
court's reasoning that may demand particular attention where foreign law is used constructively, in a manner analogous to persuasive authority. The response need not be formulaic, however. The purpose of the reference to foreign law will generally appear readily enough from judicial reasons. that are logically argued and cleatly articulated, with their intelligibility in mind.

A second concern from the standpoint of judicial method is the greater potential for manipulative use of foreign law. Manipulation may occur in various ways, ranging from misstatement of the law to an unjustifiable selection of sources. It will be remembered that Justice Roberts' concern was that a judge might use foreign law 'to incorporate his or her own personal preferences'. From the standpoint of a judge seeking a more neutral application of foreign law the problem is compounded by the reality that the interests of the opposing parties lie in advancing the foreign authorities most favourable to their cause. In the absence of guidance about the appropriate selection of foreign sources, ${ }^{146}$ their citation is not effectively controlled by reference to the obligation of barristers to assist the Court in the administration of justice'. ${ }^{147}$ By contrast, all domestic authority is potentially relevant ipso facto; in this context, indeed, the obligation of a barrister is to 'ensure that the Court is informed of all relevant decisions ... of which he is aware whether the effect is favourable or unfavourable towards the contention for which he argues'. ${ }^{148}$ The extent to which this obligation applies to references to foreign sources necessarily is unclear. ${ }^{\mathbf{1 4 9}}$

The selection of foreign sources in the course of constitutional adjudication is a question for both comparative and judicial method. For present purposes the principal focus is the latter. The former can be used to determine the criteria for selection, however, to assist foreign law to

146 The Practice Direction on the Citation of Authorities 2001 is not directed to this purpose, although its requirements might have the effect of encouraging greater attention to be paid to the purpose of referring to foreign authority and thus may indirectly affect the criteria used: <http://www.hmcourts-service.gov.uk/cms/814.htm> (viewed 11 July 2006).

147 Code of Conduct of the Bar of England and Wales, 302: <http://www.barcouncil org.uk/document.asp?languageid=1\&documentid=2827\#Paralink $>$ (viewed 11 July 2006)

${ }_{148}$ Code of Conduct of the Bar of England and Wales 710 (c). Comparable obligation are recognized in common law jurisdictions elsewhere. See also Glebe Sugar Refining Company Ltd $v$ The Trustees of the Port and Harbour. of Greenoch [1921] Scots Reports 72 .

149 Although the Practice Direction 2001, n 146 above, suggests that it applies to some extent: para 4 . And see also extra-judicial remarks by Lord Steyn, noting an expectation of 'a high standard of research and presentation from barristers' involving, in appropriate cases, 'comparative material from, say, Australia and New Zealand': 'The Role of the Bar, the Judge and the Jury' [1999] Public Law 51, 58. The rationale is also relevant for present purposes: to explore 'all available sources as to the shape of the arguments in the case being reviewed'. contribute to a process of reasoned decision-making and to defend judicial choice, at least, from charges of 'sophistry' ${ }^{150}$ or ' 'picking . . f friends'. ${ }^{151}$ It is not possible to be prescriptive about such criteria in the abstract, because the rationale for the selection of foreign experience depends in each case on the purpose for which comparison is used. In considering the general approach that might be taken, however, it is possible to see that both a quantitative and a qualitative element may be involved.

The significance of the quantitative element depends on the claim that is made. A claim that all members of a group act in a particular way requires substantiation, whether the claim is explicit or implicit. A claim that they do not, equally obviously, requires only one, well-chosen example. ${ }^{152}$ In broadly similar vein, a small number of examples can be used to identify alternatives to a single, powerful doctrine that is being urged upon the court, as in Hill and McGinty. ${ }^{153}$ More difficult are cases in which a sample of jurisdictions is used to identify options as, for example, in Western Cape. Again; assessment of the adequacy of the selection, in quantitative terms, depends on the nuance of the argument in the particular case. Examination of each jurisdiction that meets the selection criteria, whatever they may be, generally is not necessary where the purpose is to prompt reflection, provide insight, assist to frame the question for the court, suggest options, or perform any of the multitude of functions of comparative law associated with the compendious concept of 'dialogue'. In Western Cape itself any residual difficulty was avoided by the relatively modest claims that wete made for foreign law. ${ }^{154}$ On the other hand, where another jurisdiction that clearly meets the selection criteria has relevant experience that runs counter to the view favoured by the court, the reasons of the court are weakened by omitting reference to this additional source. If the omission is deliberate or even clearly incautious, it is properly characterized as 'cherry-picking'. Indeed,

150 See eg Scalia J in Roper. 'To invoke alien law when it agrees with one's own thinking and ignore it otherwise is not reasoned decision-making but sophistry': at 63 .

151 Transcript of hearing on the nomination of Justice John Roberts, $n 112$ above.

152 See eg the critique in Lawrence v Texas 359 US 558 (2003) of Chief Justice Burger's references to the history of Western civilization and to Judeo-Christian moral and ethical standards' in Bowers $v$ Hardwick 478 US 186, 196 (1986), which 'did not take account of other authorities pointing in an opposite direction': Kennedy J, for the Court.

153 In both cases the applicants had urged US precedents. In Hill the Supreme Court of Canada pointed to their rejection in South Africa and Australia; in McGinty the High Court of Australia pointed to alternative Canadian experience. In both cases, reasons wete giver for preferring one course of action to another.

154 See the judgment of Chaskalson P: "While it seems to be accepted in most of the Commonwealth...' and 'This brief and somewhat limited survey of the law as it has developed in other countries is sufficient to show ...' at [60], [61]. 
this is one context in which the obligation of counsel to refer the court to 'relevant decisions' necessarily extends to the use of foreign law.

The qualitative aspect of the selection of foreign legal experience for comparative purposes is more complex. Ran Hirschl has helpfully identified five principles of case selection that can be used for this purpose. ${ }^{155}$ A version of his category of 'most similar cases' frequently is employed in judicial reasoning, apparently instinctively, although no doubt also on the pragmatic grounds that these are the jurisdictions with which both counsel and judges are most familiar. Importantly, they also have the advantage of lessening the challenge of comparative method.

In four of the cases used by way of illustration in this chapter, Hill, McGinty, Western Cape, and Jackson, relevant similarities in the legal systems, constitutional arrangements, and historical experiences of the jurisdictions to which reference was made suggest that the selection might be justified on the basis of similarity. The rationale for the selection of the United States, Germany, Canada, and the ECHR in Rubinstein is less obvious, however. As established western democracies, these four jurisdictions have enough in common to be useful to establish that there is a link between questions about the respective scope of legislative and executive power and the key constitutional principles of separation of powers, rule of law, and democracy, which was one of the purposes for which the Court used them. Given differences between the legal systems of these various jurisdictions and the design of the legislative and executive structures over which they adjudicate, however, they form a less rational group for the purpose of determining where the line is drawn in Israel between an exercise of legislative and executive power. The difficulty here overlaps with questions of comparative method and it is taken up in that context again below.

Courts do not necessarily-articulate the rationale for referring to the legal experience of particular foreign jurisdictions and, by inference; for not referring to the legal experience of others. Articulated or not, however, the integrity of the judicial process requires that there be a rationale and that the conclusions drawn from foreign law are tailored to it. The more substantial a role played by foreign law in the reasoning process, the more useful it may be explicitly to state the criteria for selection on which the court relies.

155 Ran Hirschl, "The Question of Case Selection in Comparative Constitutional Law' (2005) 53 American Journal of Comparative Law 125, 133-52. His categories refer to 'most similar cases', 'most different cases', 'prototypical cases', 'most difficult cases', and 'outlier cases'.

\section{Comparative Method}

\section{Does Comparative Method Matter?}

It was argued in the preceding section that references to foreign law in constitutional adjudication complicate aspects of judicial method, requiring greater attention to be paid to the rationale for the selection of sources and care to be taken in the manner in which they are used and in the weight accorded to them.

The question in this section is whether there are other methodological demands that references to foreign law place on courts that might compendiously be attributed to comparative method. The challenge of comparative method may involve no mote than getting the foreign legal experience right: a task that by definition is more complex in relation to foreign than to domestic law. But comparative method may involve broader factors as well, directed to ensuring that the comparison is apt and that the conclusions drawn from it are reliable.

Given the kinds of use often made of foreign law in constitutional adjudication it may be possible to argue that comparative method is relatively unimportant. If foreign legal experience is merely a general reservoir of ideas on which a judge draws during one or more phases of the adjudicative process for aid in reaching an essentially domestic solution, does it matter whether the foreign experience itself is fully understood? Does it matter whether a foreign practice or doctrine is still in use in its country of origin? Does it matter whether the source of the idea is a dissenting judgment or a decision that subsequently was overturned on appeal?

The answer to these questions necessarily depends in part on the particular use that is made of foreign law. In principle, however, both the quality of the reasons of a court and the advantages of referring to foreign law are enhanced by paying appropriate regard to these methodological questions. ${ }^{156}$ Common law judicial method calls for reasoned judgment, which also serves to underpin the legitimacy of the judicial function at the higher appellate levels where the courts exercise considerable discretion in developing the law and where the potential for conflict with other branches is at its height. The quality of judicial reasoning arguably is more important, rather than less, in relation to the use of foreign law. This is

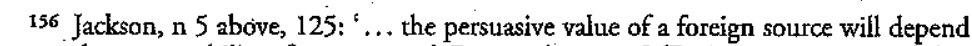
on ... the comparability of contexts ....'. But see also at 126 : 'Determining comparability
is a serious challenge...? 
both because the practice of referring to foreign legal experience draws on a conception of judge-made law as an outcome of a reasoning process and because the usual safeguards of the adversary system are weakened in relation to foreign law. ${ }^{157}$ Adequate attention to methodology may deflect criticism on legitimacy grounds. 158 Failure to pay due regard to comparative method, on the other hand, may unnecessarily expose a court's reasoning to criticism, inhibiting the utility of the reference to foreign law and, in extreme cases, reducing it to a rhetorical device.

If this is correct, the question that remains is what comparative method requires in the context of constitutional adjudication. A useful starting point is the insight that might be derived from comparative private law, where a vigorous debate on methodological issues has for some time been under way.

\section{Insights from Comparative Private Law}

The discipline of comparative law, with its almost exclusive focus on private law, ${ }^{159}$ has a long history spanning the entire twentieth century. 160 Comparative scholars endorse the value of comparative law as offering a greater variety of solutions than could be thought up in a lifetime by even the most imaginative jurist who was corralled in his own system'. ${ }^{161}$ But comparative law scholarship warns also of the difficulties inherent in drawing conclusions from the legal experience of different national jurisdictions. Every legal phenomenon forms part of a larger legal system; form and practical operation may differ; both, but in particular the latter, may be affected by the legal, political, economic, social, or cultural context in which the phenomenon is found; change, presently driven by the contradictory influences of localization and globalization, is likely over time; ${ }^{162}$ and there are internal perspectives on legal systems, including assumptions and beliefs that insiders take for granted, 163 which outside observers will find it difficult, if not impossible, to fully grasp.

157 Although $\mathrm{cf}$ Jackson, $\mathrm{n} 5$ above, 126 noting that the deficiency may in part be supplied by other members of a multi-member court.

158. See eg Young, n 5 above, 152: 'The hallmark of persuasive authority is engagement with the reasons for a practice or a decision rather than the counting of noses' (emphasis in original).

${ }_{159} \mathrm{~K}$ Zweigert and H Kotz, An Introduction to Comparative Law (3rd edn) (Oxford: Oxford University Press, 1998), 3, referring to 'comparative private law, the heartland of all comparative law'.

160 ibid 2-3.

161 ibid 15.

162 Roderick Munday, Accounting for an Encounter' in Legrand and Munday n 19 above, 3,20 .

163 James Whitman, 'The Neo-romantic Turn', in Legrand and Munday, $n 162$ above, 312,315 .
One influential solution to the difficulties of comparative law.was, and to a lesser degree remains, the analytical technique of functionalism. Functionalism seeks to meet the reality that 'similar institutions can fulfil different functions in different societies ... and ... that similar functional needs can be fulfilled by different institutions'. ${ }^{164}$ It thus takes function as the common or shared element between jurisdictions, comparing different ways in which similar functions are achieved. It claims the advantages of neutrality in pursuing the comparative project ${ }^{165}$ and presents itself as a particularly useful technique for comparison between different systems of law. 16.6

Functionalism necessarily assumes that legal systems perform functions that are sufficiently similar and sufficiently discrete to be used for comparative purposes in this way. In recent years these and other features of it have been the focus of criticism in the face of what has been termed the new critical comparative law. ${ }^{167}$ Some of the criticisms have been directed at the claimed advantages of functionalism questioning, for example, its neutrality ${ }^{168}$ and the utility for many comparative purposes of the very notion of functional equivalence, which chooses one function to the exclusion of others. ${ }^{169}$ Other criticisms are directed at the assumptions of functionalism, with their seemingly universalist tendencies, suggested by the dependence of this methodological approach on the similarity of problems and its correspondingly weaker emphasis on other aspects of contextual difference. By contrast, some of the new theoretical approaches focus on difference, emphasizing and prioritizing the depth of diversity between legal systems for which functionalism cannot fully account. ${ }^{170}$ Suspicion of functionalism is fuelled by observations by leading functionalist scholars that comparative law provides a means for identifying 'which solution of a problem is the best' and for 'the international unification of law'. 171

164 Ralf Michaels, 'The Functional Method of Comparative Law', 20, < http://eptints.law.duke.edu/archive/00001249/01/Functional_Method.pdf>, forthcoming in Mathias Reimann and Reinhard Zimmerman (eds), The Oxford Handbook of Comparative Law (Oxford:Oxford University Press).

165 Zweigert and Kotz, n 159, 35.

166 Michaels, n 164 above, 21 : '... functionalist comparison should be able to overcome the epistemic/doctrinal difference between civil and common law by ignoring it as irrelevant'. See also Zweigert and Kotz, n 159, $37^{\prime}$ '... the Common Law, with its inductive and makeshift habits, ptoduces low-level legal institutions specially adapted to solve particular concrete problems'.

168 Michaels, $n 164$ above, $27 . \quad 169$ ibid 34.

170 Legrand and Munday, n 19 above; Mark Van Hoecke (ed), Epistemology and Methodology of Comparative Law (Oxford: Hart, 2004); William Ewald, 'Comparative Jurisprudence (1): What Was It Like to Try a Rat?" 143 (1994-5) University of Pennsylvania Law Review 1889.
171 Zweigert and Kotz, n 159, 8, 24. 
The debate on methodology in comparative law is somewhat selfabsorbed, but it has done a service to the discipline, challenging old ideas and encouraging new ones. For the most part, however, it has had relatively little impact on comparative constitutional law. ${ }^{172}$ One reason for the gulf between the two branches of the discipline lies in the assumption about the desirability of the convergence of comparative private law, which was associated with functionalism, and which was deemed to be inapplicable to public law. Whether either assumption necessarily is correct is presently beside the point. Rejection of convergence as an ideal by the new critical approaches to comparative law in one sense offers a. means for bridging this version of the public/private divide. At the same time, however, the new emphasis on diversity and on the difficulty of adequately understanding the other further complicates the methodological challenge for comparing constitutions, with their deep roots in history and political practice.

\section{Comparative Method and Constitutional Law}

Two questions in particulat are raised by this brief survey of the debate on methodology in comparative private law for the comparative methodology of courts that refer to foreign law in the course of constitutional adjudication. The first is the applicability of functionalism. The second is the relevance of difference, including the extent to which contextual difference must be explored in drawing conclusions from foreign experience for domestic constitutional purposes.

Consideration of the function of particular legal phenomena is a useful tool in comparative conistitutional law, as in other branches of comparative law: Arguably, for example, it informed the decision of the Supreme Court of Canada in Hill.not to adopt the United States standard of actual malice for the purposes of defamation law. Cory J, for the Court, noted that the standard adopted in New York Times $\nu$ Sullivan sought to protect the freedom of the press from attempts to inhibit it through defamation suits at a time when passions about desegregation ran high while 'a review of jury verdicts in Canada reveals that there is tio danger of numerous large awards threatening the viability of media organisations'. ${ }^{173}$ Function is not explicitly considered, however, and the reasoning of the Court might equally be understood as taking the social, political, historical, and legal context in which Sullivan was decided into account.

172 For an exception see Mark Tushnet's treatment of functionalism at n 115 above,
1225.
The usefulness of functionalism for the purposes of constitutional adjudication is limited, however, by the generality of some of the key functions that might be considered to be similar across jurisdictions in constitutional law. It can be assumed for the purposes of argument, albeit at the cost of ignoring important differences in detail, ${ }^{174}$ that all western constitutional systems provide for the performance of broadly similar functions in terms of, for example, limiting the potential for abuse of power by distributing power between different branches of government; securing a rule of law; enabling democracy; and protecting human rights. At this level, however, the function is too general to provide the basis for a comparison that is likely to assist with most of the questions likely to come before a court. Different constitutional systems perform these functions in a multitude of different ways, through institutions and principles that in many cases have developed organically over time, which complement and compensate for each other.

The difficulty is illustrated by Rubinstein. On one view; the reasoning of the Supreme Court of Israel might be understood as a form of functional comparison, using separation of powers, the rule of law, and democracy as the functions that are common to all the jurisdictions to which the court referred. But the mixture of institutions and principles through which such purposes are served in the United States, Germany, and Canada respectively is too diverse to enable the point at which the line between legislative and executive power should be drawn in Israel to be readily elucidated by functional comparison at this level, in the way that the Court sought to do. ${ }^{175}$ In this instance, comparative method required closer attention to be paid to the structural logic of the constitutional systems to which the Court referred to determine whether there were other relevant differences between them that would affect the conclusions that the Court drew from the comparison.

Justice Breyer's opinion in Printz ${ }^{176}$ provides another possible example of a functional analysis with less than satisfactory results. The judge

174 Thus in McGinty the High Court accepted the view of successive Canadian courts that there are differences between the 'evolutionary'. democracy of Canada and Australia and the democratic arrangements born of revolution in the United States: eg Gummow J, (1995) 186 CLR 140, 287-8. The explanation may be contested; the reality of difference nevertheless remains.

175 See eg the argurnent at [23], in which the Court uses decisions of the Canadian Supreme Court pursuant to the Canadian Charter of Rights and Freedoms to establish the link between human rights protection, democracy, and the notion that rights can only be limited by law; but also, less persuasively, uses the Canadian and other decisions taken pursuant to codified rights instruments to establish that the 'fundamental criteria' for administrative arrangements must be established by legislation.

176 Printz v United States 521 US 898, 976-7 (1997). 
identified as a 'common legal problem' the challenge of 'reconciling central authority with the need to preserve the liberty enhancing autonomy of a smaller constituent governmental entity'. ${ }^{177}$ On this basis he turned to the federal-type arrangements of Switzerland, Germany, and the European Union to cast 'empirical light' on the consequences of tackling the problem by providing that 'constituent states, not federal bureaucracies, will themselves implement many of the laws, rules, regulations, or decrees' of the central authority. He used the comparison to support his view that the United States Constitution did not preclude the assignment of federal duties to State officials. In doing so, he acknowledged the possibility of 'relevant political and structural differences' between the American and European federations, but did not pursue them. Failure to do so diminished the force of the comparison. The horizontal division of powers is a systemic feature of European federations, supported by a range of institutions, principles; and practices directed to making the system work smoothly and to safeguarding the position of both the centre and the constituent units. These additional features also required consideration to determine whether the comparison was apt.

A second issue raised by consideration of the debate within comparative private law is the relevance of context. The textual and structural setting for the foreign legal experience on which the court draws are almost always relevant. Thus in Jackson, Lord Steyn's omission of any acknowledgement of the difference in the conception of sovereignty between the United Kingdom and its former dominions weakened the integrity of his argument; and also denied him the opportunity to use dominion experience reflectively, to evaluate the conception of sovereignty that so far has prevailed in the United Kingdom. For the most part, however, the essentially legal dimensions of context are taken adequately into account by courts, applying their customary legal techniques. $\mathrm{A}$ more difficult question is whether and when courts should take into account other dimensions of the context that might affect a more complete understanding of the foreign experience.

The somewhat unsatisfying answer must be that it depends on the circumstances including; in particular, the use that is made of foreign law. Where a court is urged to adopt a new rule, drawing on a foreign source, deeper consideration of context may be appropriate. Indeed, this occurred in Hill, where the Supreme Court of Canada considered both the sociopolitical context in which New York Times $v$ Sullivan was decided and the practical consequences in the United States of adoption of the actual

$$
177 \text { Ibid. }
$$

malice standard in deciding that it should not be applied in Canada. On the other hand, where foreign law is invoked less directly, as an aid to a court in developing its own view of the law, deep contextual inquiry may be less important. Thus in Western Cape foreign experience was used to identify a range of approaches that had been taken in other jurisdictions in order to identify any constitutional limits on the extent to which legislative power could be delegated to the executive branch. In evaluating these varying approaches, Chaskalson $P$ took into account both structural differences in the systems of government of the several jurisdictions ${ }^{178}$ and historical differences ${ }^{179}$ that might account for some of the choices that had been made. The Court did not go further, however, to examine, for example, whether in any of these jurisdictions there were non-legal mechanisms by which excessive delegation might be controlled. In the circumstances, it was not necessary to do so. Foreign law had served its purpose of prompting reflection on the answer that the South African Court should give to the necessarily doctrinal question that was before it, which would be responsive to the language of the Constitution, construed in the light of the country's own history'..$^{180}$

No doubt there is more to be said about comparative method in constitutional adjudication, both generally and in relation to these cases. Tentative conclusions nevertheless might be drawn as follows. First, counsel, judges, and constitutional scholars should at least be aware of the methodological issue. Secondly, courts should avoid what Justice Kate O'Regan has referred to as 'shallow comparativism'. ${ }^{181}$ 'Thirdly, what amounts to shallow comparativism will depend on the use that is made of foreign legal experience, in addition to other factors. Where the role played by reference to foreign experience is not insubstantial, the appropriate method is likely to involve at least an accurate and up-to-date account of the foreign experience; sufficient contextual understanding of the foreign experience to enable it to be adequately evaluated for the purpose for which it is used; and an explanation of where the comparison sits in the reasoning of the Court, to enable others to learn from it and to evaluate it. Fourthly, however, on the other hand, O'Regan J's warning against excessive methodological demands also is relevant here: 'To forbid

$17 \mathrm{~B}$ These included, importantly, the distinction between a presidential and a parliamentary system, the significance of which ultimately was dismissed by Chaskalson $P$ for instant purposes: at 31 .

179 In particular, the continuing influence in many Commonwealth countries of the UK approach to the delegation of legislative power, forged in the context of parliamentary, as opposed to constitutional, supremacy: at 29-37.

${ }_{181}$ NKv Minister of Safety of Security 2005 (6) SA 419 (CC), $24-5$.
180 At 36. 
any comparative review because of [the risks associated with comparative method] would be to deprive our legal system of the benefits of the learning and wisdom to be found in other jurisdictions.' ${ }^{182}$

\section{Conclusion}

In general terms, the response to the question raised in the title of the chapter may be summarized as follows.

In constitutional adjudication in common law states, necessarily excepting the United States, no problem of legitimacy is raised by the mere fact of reference to foreign legal experience of either a constructive or reflective kind. On the contrary, the practice is accepted as a valuable one that enables national constitutional systems to draw on a wider pool of experience and ideas without compromising their constitutional autonomy or their capacity for national self-development.

The methodology that courts employ for the purpose is potentially more problematic, however. The demands of method should not be exaggerated, given the nature of the uses typically made of foreign legal experience. On the other hand, as an often significant dimension of the reasoning of a court, the method employed in drawing on foreign sources must sustain the conclusions that are drawn. For the most part courts have handled these requirements instinctively in the past with results that, judging by the small sample of cases used here, are often reasonable but sometimes patchy. In this first decade of the twenty-first century, however, there is a range of reasons why references to foreign law in constitutional cases might begin to attract closer, and not necessarily friendly, scrutiny. These include the continuing fall-out of the debate on the use of foreign law in the United States; the impact of the new emphasis on difference in comparative private law; the growing nationalism that is a sign of the times, whether as a reaction against increasingly heterogeneous communities, threats of terrorism or globalization; and the mounting hostility of governments to what they perceive as judicial activism.

It has been argued in this chapter that this aspect of the constitutional adjudicative process deserves more conscious attention, in both the formulation and the articulation of reasons by courts. In essence, what is required is adherence to the familiar legal standards of accuracy, relevance, and justifiability, applied to the somewhat different circumstances of the use of foreign law. Often, a court can draw its conclusions by reference to legal context, including constitutional history and structure. In some cases, however, it is necessary to inquire further into the wider context from which the foreign experience emerged and within which it presently functions. Whether and when this is so will vary between cases, by reference to the purpose of the reference to foreign law.

One final complication is that the field necessarily is changing. The principal catalysts for change are supranational and international law and the forces of globalization. These both manifest and further encourage convergence of the broad conceptual foundations on which constitutions are based. If the process extends further into doctrine and institutional. design it will force corresponding adjustment to comparative constitutional method.

182 İbid. 


\section{University Library}

\section{- M M I N E R VA A gateway to Melbourne's research publications}

Minerva Access is the Institutional Repository of The University of Melbourne

Author/s:

SAUNDERS, C

Title:

Comparative constitutional law in the courts: Is there a problem?

Date:

2007

Citation:

SAUNDERS, C. (2007). Comparative constitutional law in the courts: Is there a problem?. Holder, J (Ed.). O'Cinneide, C (Ed.). Current legal problems 2006, (1), pp.91-127. Oxford University Press.

Persistent Link:

http://hdl.handle.net/11343/25571 